hazu zrilykh rodovyshch // Komunalne hospodarstvo mist. Seriia: Tekhnichni nauky ta arkhitektura. 2017. No. 134. P. 52-57.

13. Abdumula M. F. Heavy Hydrocarbon Testing Methodology // The Micro CAD International Scientific Conference. Miskolc, 2004

14. Abdumula M. F. Influence of Paraffin Flocculation in Crude Oil Tran sported Pipelines with Economic View of Pigging Process // 1st International Conference and Exhibition in Oil Field Chemicals. Tripoli, 2003.

15. Abdumula M. F. Wax Precipitation in Crude Oil Tran sporting Pipelines // The Micro CAD International Scientific Conference. Miskolc, 2004

16. Alyaari M. Paraffin wax deposition: Mitigation and removal techniques // SPE Saudi Arabia section Young Professionals Technical Symposium. 2011. P. 1-10. doi: http://doi.org/ 10.2118/155412-ms

17. Gupta A., Sircar A. Introduction to Pigging \& a Case Study on Pigging of an Onshore Crude Oil Trunkline // Journal of Latest Technology in Engineering, Management \& Applied Science. 2016. Vol. 5, No. 2. P. 18-25. URL: https://www.researchgate. net/publication/307583466_Introduction_to_Pigging_a_Case Study_on_Pigging_of_an_Onshore_Crude_Oil_Trunkline (Last accessed: 16.01.2018)

18. Skorobagach M. A. Problemy ekspluatatsii sistemy sbora gaza na mestorozhdenii Medvezh'e // Tekhnologii nefti i gaza. 2011. No. 6. P. $42-47$
Grudz Volodymyr, Doctor of Technical Sciences, Professor, Head of Department for the Construction and Repair of Gas Pipelines and Gas Reservoirs, Ivano-Frankivsk National Technical University of Oil and Gas, Ukraine, ORCID: https://orcid.org/0000-00031182-2512,e-mail:v.grudz@nung.edu.ua

Marushchenko Victor, Head of the Department of Ground Infrastructure, JSC «UkrGasVydobuvannya», Kyiv, Ukraine, ORCID: https:// orcid.org/0000-0001-8732-2712, e-mail: marushchenko@ugv.com.ua

Bratakh Mikhailo, PhD, Senior Researcher, Head of Gas Transportation Department, Ukrainian Research Institute for Natural Gases, Subsidiary of the UkrGasVydobuvannya, Joint-Stock Company, Kharkiv, Ukraine, ORCID: https://orcid.org/0000-0002-5464-7921, e-mail: mikhailo_bratakh@ukr.net

Savchuk Myroslav, Head of Industrial Pipelines And Electrochemical Protection Sector, Department of Ground In rastructure, JSC «UkrGasVydobuvannya», Kyiv, Ukraine, ORCID: https://orcid.org/0000-00030879-0476,e-mail: mirosavchuk@gmail.com

Filipchuk Oleksandr, Division for the Collection, Preparation and Transport of Hydrocarbons, Department of Ground Infrastructure, $J S C$ «UkrGasVydobuvannya», Kyiv, Ukraine, ORCID: https://orcid.org/ 0000-0003-4255-1663, e-mail: oleksandr.filipchuk@outlook.com

UDC 628.88

DOI: $10.15587 / 2312-8372.2018 .135783$

\section{Basok B., Tkachenko M., Nedbailo A. Bozhko I.}

\title{
RESEARCH INTO ENERGY EFFICIENCY OF THE UNDERFLOOR HEATING SYSTEM, ASSEMBLED DRY
}

Об’єктом дослідження є теплотехнічні параметри роботи фрагмента системи підлогового опалення сухого монтажу в умовах реальної експлуатащї, який встановлено в лабораторному приміщенні.

Одним з найбільш проблемних місць при проведенні експериментальних досліджень виявилась мала площа досліджуваної системи опалення, відносно об'єму приміщення. При значних добових коливаннях температури зовнішнього повітря виявлялись складнощі з виходом роботи системи опалення на квазістаціонарний режим.

В ході дослідження встановлено вплив товщини теплоізоляційного шару під опалювальним контуром на зміну густини теплового потоку від поверхні підлоги до повітря в опалювальному приміщенні. Зазначається, що система підлогового опалення сухого монтажу має малу теплову інерційність завдяки відсутності відносно товстого шару монолітної бетонної плити (із високою питомою теплоємністю), в якій зазвичай облаштовується контур системи опалення.

Зокрема встановлено, що використання керамічної плитки, як фінішного покриття, в порівнянні із ламінатом, суттєво зменшує загальний термічний опір теплопередачі від теплоносія до повітря в приміщенні, що опалюється. При цьому наявність алюмінієвої теплорозподільної пластини, з якою безпосередньо контактує зовнішня поверхня труби опалювального контуру, позитивно впливає на рівномірність розподілу теплового поля в площині підлоги. Це в свою чергу призводить до зменшення термічних напружень у фінішному покритті.

Розрахунки показують, що кількісне регулювання теплового навантаження такої системи, завдяки зміні витрати теплоносія, виявляється менш ефективним аніж якісне, за допомогою зміни його температури.

Експериментальні дослідження демонструють, що густина теплового потоку на поверхні підлоги збільшується майже вдвічі при використанні керамічної плитки у порівнянні із ламінатом при всіх, майже ідентичних, інших теплотехнічних параметрах системи.

Проведені дослідження дають змогу розробити математичну модель роботи системи підлогового опалення сухого монтажу, за допомогою якої, стане можливим провести оптимізаційні розрахунки та вдосконалити конструкцію даного опалювального приладу.

ключові слова: водяне підлогове опалення, опалювальний контур, теплове навантаження, термічний опір теплопередачі, тепловий режим приміщення.

\section{Introduction}

Global trends in increasing the energy efficiency of heating supply systems in general are aimed at the utilization of natural renewable energy sources, damped secondary energy resources, decentralization of heat supply, as well as a transition to low-temperature heating systems. When applying heat pump installations as part of heat supply 
systems, predominant are the low-temperature systems of water underfloor heating. This is due to the fact that at such heating the area of heat exchange between a heat carrier and air in a room is much larger in comparison with other systems and, accordingly, the temperature potential of the heat carrier can be reduced. In addition, the underfloor heating provides the most comfortable sanitation conditions for the stay of a person in premises.

Therefore, it is a relevant task to study influence of the design and a finishing coating of the low-temperature underfloor heating systems on their thermal-engineering characteristics and energy efficiency.

\section{The object of research and its technological audit}

The object of research is the heat-technical characteristics of operation of a fragment of the system of underfloor heating, assembled dry, with an area of $6.36 \mathrm{~m}^{2}$ and the size of $1.2 \times 5.3 \mathrm{~m}$.

The heating system was arranged in the middle of the laboratory facility with an area of $18 \mathrm{~m}^{2}$ and the size of $3 \times 6 \times 3 \mathrm{~m}$. Its mounting scheme is shown in Fig. 1 .

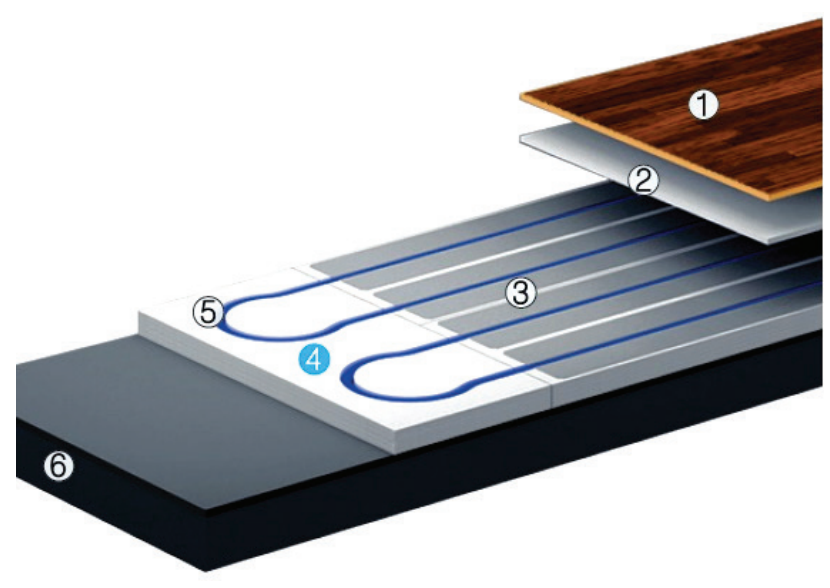

Fig. 1. Diagram of the underfloor heating, assembled dry: 1 - finishing flooring (laminate, ceramic tiles); 2 - substrate (cellulose, gypsum fiber); 3 - aluminum heat distributor; 4 - foam polystyrene plate; 5 - pipe in a heating circuit; 6 - starting floor

The heating circuit is made of the PeX metallic polymeric pipe with an outer diameter of $16 \mathrm{~mm}$ and a wall thickness of $2 \mathrm{~mm}$. Thicknesses of the aluminum heat distributor and the plate made of extruded foam polystyrene with grooves (channels) were, respectively, $0.2 \mathrm{~mm}$ and $40 \mathrm{~mm}$ (total, varies in different experiments).

By using such a technical solution, we thermostated air of the room according to sanitary-hygienic norms $\left(20 \pm 2{ }^{\circ} \mathrm{C}\right)$ under quasi-stationary conditions. Depending on the temperature of ambient air, we discretely assigned the values for electric power (thermal load) at the flow-through electric water heater to compensate for the heat losses in the premises at a constant flow rate of the heat carrier in a heating system circuit. To adjust the power of the electric water heater VPO-5,5/220, we used the stabilized source SSK-1-3-220 (Russia) with electric current $220 \mathrm{~V}$ at $50 \mathrm{~Hz}$, the laboratory auto-transformer RNO-250-5 (Ukraine) and the portable measuring Kit K-50 (Ukraine), which registered electric current, electric voltage, and power, in the course of our research.
Experimental values for electrical power were set: 200, $300,400,500$, and $600 \mathrm{~W}$. The experiment continued until the stabilization of the temperature field distribution in the air above the floor and in the layers of the premises floor (the absence of change in the values of temperature and heat flow at specific locations of measurement). The time it took for the examined system with a laminate coating to enter the quasi-stationary operating mode was about 8-12 hours depending on the heat load.

One of the most problematic issues when conducting experimental research was a small area of the examined heating system, relative to the volume of the premises. Considerable daily ambient air temperature fluctuations resulted in certain difficulties while the heating system entered the quasi-steady mode.

\section{The aim and objectives of research}

The aim of present research is to identify ways to improve the overall energy efficiency of the underfloor heating system, assembled dry. To achieve the set aim, the following tasks have been solved:

1. To research experimentally the effect of thickness of the heat insulating layer on the properties of heat transfer from the heat carrier to the air in the premises.

2. To investigate experimentally the influence of the type of a finishing coating in the system of underfloor heating, assembled dry, on the properties of heat transfer from the heat carrier to the air in the premises.

3. To determine the optimal operational mode and a method to control the heat output of the underfloor heating system.

\section{Research of existing solutions of the problem}

Insufficient attention has been given to studying the process of heat transfer in the systems of underfloor heating. The basic method of research is mathematical modeling of the operation of a warm water floor under different boundary conditions. Thus, papers [1,2] considered a classic problem on modeling the heat supply to premises using an underfloor heating system. The authors introduced the concept of equivalent thermal resistance - using which may enable the optimization calculations and selection of a finishing coating composition. However, a significant number of simplifications of geometrical shapes and boundary conditions degrade the accuracy of the results obtained.

Several papers address the development of non-stationary models of the thermal interaction between an underfloor heating system and air inside the premises under different conditions. Authors consider the dynamics in heating the premises [3] and propose non-standard multi-layer heating systems [4]. However, it is difficult to evaluate the adequacy of their work without verification of these models on the basis of experimental studies. These studies lack any analysis of the effect of thermal-physical properties of the floor finishing coating on the efficiency of underfloor heating.

Several articles report studies into operation of the system of underfloor heating and the effect of furniture on the distribution of temperature and a thermal regime in the premises. Thus, paper [5] investigated a living premises with an underfloor heating system in the presence of furniture. The authors present results of mathematical 
modeling and their comparison with experimental data. The most detailed analysis of the impact of a floor finishing coating is given in [6]. The study was conducted using a warm water floor laid in a concrete pillow in line with a standard method. The authors constructed a mathematical model and carried out experimental study, which showed expediency of using materials with high thermal conductivity as a finishing coating. Another important factor is the thermal insulation of the surface over which an underfloor heating system is assembled.

Another area of research into low-temperature heating devices is the optimization calculations and search for innovative solutions when creating systems of underfloor heating. Paper [7] considers the model and results of calculation of the floor heating device, which exploits effects of phase transitions of the heat carrier during heat supply from a heat pump. Articles [8, 9] examine the possibility of joint application of low-temperature and classic heating appliances in homes. However, there are no data on the experimental research and evaluation of the effectiveness of such systems of underfloor heating.

Work [10] explores the operation of an underfloor heating system along with a heat pump of the «air-water» type. A series of experiments were conducted, which resulted in the detected economically optimal mode of operation of a given heating system.

Thus, the research into and improvement of the operation of an underfloor heating system is a promising task related to increasing the efficiency of heat supply systems to premises. However, the cited authors consider «classic» systems of underfloor heating, namely tubular heat exchangers, which are built into concrete or cement pillows. At the same time, little attention is paid to the development of new designs for the underfloor heating systems and to studying influence of the finishing coating on the effectiveness of their operation and a temperature regime of premises under conditions of actual operation.

\section{Methods of research}

Undertaking the experimental research implied measuring, in real-time mode, the density of heat flow and temperature in specific locations of the heating system and the temperature of air inside, using thermoelectric converters, followed by an analysis of the efficiency of heat transfer between the heat carrier and air in the premises.

While conducting experiments, the following values were registered by a system of secondary control-measuring instruments at intervals of 10 minutes:

- air temperature for the height of the room at 16 measuring points (we determined the average temperature $t$ );
- temperature of the external air;

- temperature at different control points (including at the floor surface above the feed and reverse pipelines) in the underfloor heating system, both horizontally (in various locations relative to the heating circuit) and vertically, under the heating area and between layers of the system $(-430.0 \ldots 0.0 \mathrm{~mm})$;

- value of the heat carrier temperature at the inlet and outlet of the heating circuit;

- value of the heat flow density under the floor, between different layers of the floor, at the floor surface in specific locations relative to the heating circuit (rectangular designations) (Fig. 2).

Using readings from the heat meter Apator LQM-III-K (Poland), which is installed before the inlet to the system circuit, we determined a discrete heat load, which corresponded to the installed power for the electric water heater.

When conducting all experiments, we chose days with a minimum daily fluctuation of values in the outdoor temperature and its motion speed (wind). That ensured the maximum proximity to the permanence of heat losses in the premises over time.

According to the specifications, one should accept, in the areas of the greatest cooling in premises (close to external enclosures), that temperature at the surface of a heated floor should does not exceed $35{ }^{\circ} \mathrm{C}$. That was also taken into consideration while carrying out experiments (accordingly, the heat load was not exceeded).

In this case, the overall relative error of measuring the basic physical quantities under the automated mode was not more than $5 \%$.

We conducted a series of experiments with the values of the volumetric flow rate of heat carrier in the circuit of underfloor heating of $G=0.102$ and $0.058 \mathrm{~m}^{3} / \mathrm{h}$, different total thickness of the foam polystyrene plate of 40,50 , $80 \mathrm{~mm}$, and finishing coatings made of laminate and tile. Laminate with a thickness $8 \mathrm{~mm}$ was laid in line with technology onto a cellulose substrate with a thickness of $4 \mathrm{~mm}$, and 8-mm thick ceramic tiles were glued, using a specialized mixture, onto an aluminum heat distributor.

If we are to consider premises with water underfloor heating as a heat exchanger between the heat carrier in a heating circuit and air in the room, it is possible to write the equation of heat transfer for a given system:

$$
Q=k \cdot F \cdot \overline{\Delta t},
$$

where $k$ is the coefficient of heat transfer in the system of underfloor heating, $\mathrm{W} /\left(\mathrm{m}^{2} \cdot \mathrm{K}\right)$ (it takes into account a considerable number of factors related to the design of underfloor heating); $F$ is the heat exchange surface area, $\mathrm{m}^{2}$.

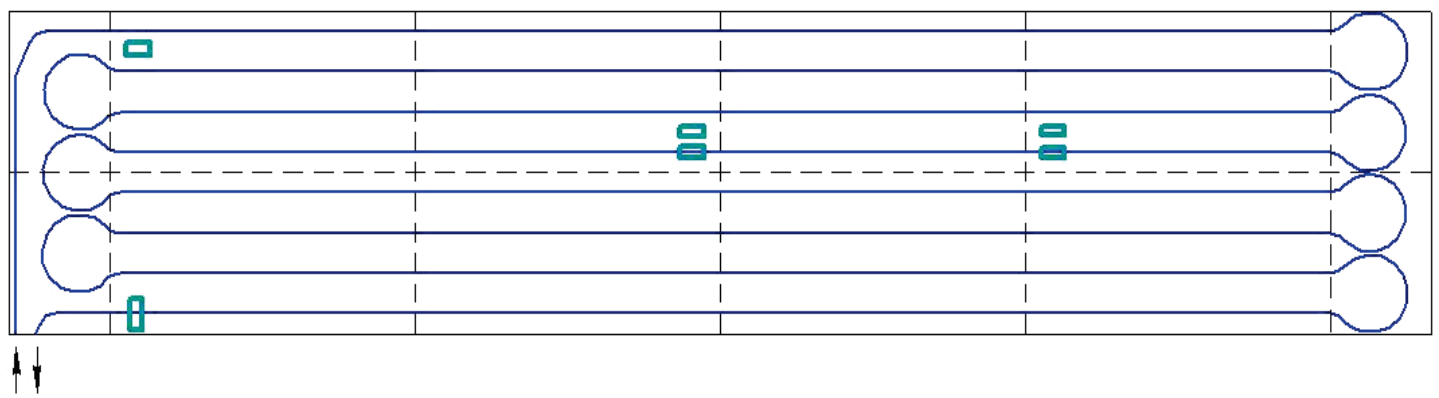

Fig. 2. Arrangement of sensors in the system of underfloor heating 
In this case, the average difference between temperatures of water and air (a temperature head) $\overline{\Delta t}$ is derived here from formula [11]:

$$
\overline{\Delta t}=\frac{\Delta t_{\max }-\Delta t_{\min }}{\ln \frac{\Delta t_{\max }}{\Delta t_{\min }}},
$$

where $\Delta t_{\max }$ is the temperature difference between water at the inlet to the heating circuit and air in the premises; $\Delta t_{\min }$ is the difference between water temperature at the outlet from the heating circuit and air in the premises, ${ }^{\circ} \mathrm{C}$.

Specific heat flow from the surface of the floor, which can be provided by the system of water underfloor heating of a certain design, is directly proportional to the average temperature difference between a heat carrier in the system and air in the heated premises:

$$
q=k \cdot \overline{\Delta t}
$$

The above coefficient accounts for the thermal resistances of a pipe in the heating circuit and of a monolithic heating slab (panel), inside which a heating circuit is installed, a finishing layer of the floor, layers of thermal insulation under the heating circuit. As well as the geometrical parameters of the system: pitch of laying a pipe and its diameter [12]. This gives rise to computational difficulties related to analytical determining of the heat transfer coefficient of such a system.

\section{Research results}

The results of calculations that we derived can be represented in the form of nomograms of thermal load for separate designs of water underfloor heating whose thermaltechnical parameters are investigated. The nomograms were constructed for different values of thickness of thermal insulation (foam polystyrene plates), volumetric flow rate of heat carrier in the circuit, outdoor temperature (heat losses in the premises) and the floor finishing coating.

The nomograms allow us to determine the heat transfer coefficient $k$. Its magnitude is equal to the value of the tangent of the inclination angle in the nomogram of thermal load in the heating system to the horizontal axis of the abscissa.

By using the constructed nomograms, given the assigned temperature in a room and the temperature diagram of heat carrier in the system, it is possible to determine the required area for an underfloor heating system whose heat output capacity would provide for known heat losses from the premises. These nomograms could form the basis for an engineering technique of the thermal calculation of low-temperature water underfloor heating systems. Results of the experiments are represented graphically in Fig. 3-5.

Fig. 3 shows that a significant increase in the average temperature of the floor surface is predetermined by the use of ceramic tiles as a finishing coating. This is explained by the greater value of the thermal conductivity coefficient of a given material. At the same time, different flow rate of the heat carrier over a certain range has almost no impact on a change in the laminate surface temperature.

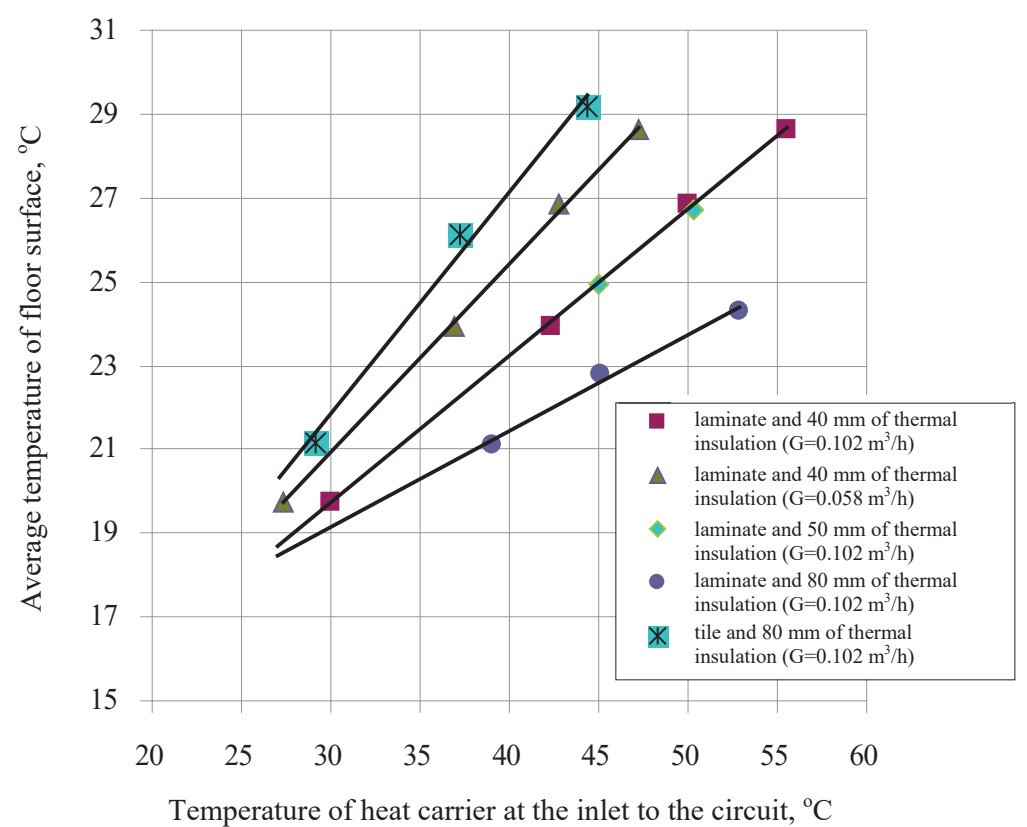

Fig. 3. Dependence of the average temperature of floor surface on temperature of the heat carrier at the inlet to the circuit of underfloor heating

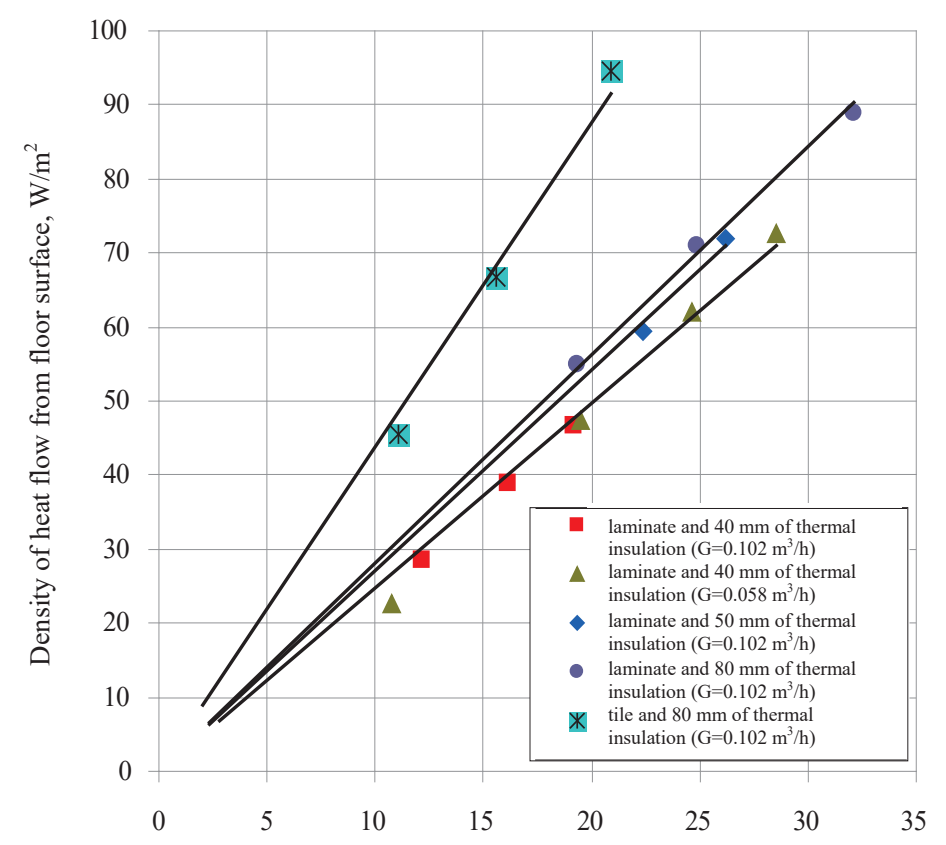

Difference between average temperatures of heat carrier and air, ${ }^{\circ} \mathrm{C}$

Fig. 4. Dependence of density of the heat flow from the floor surface on the average difference between temperatures of water and air in premises 


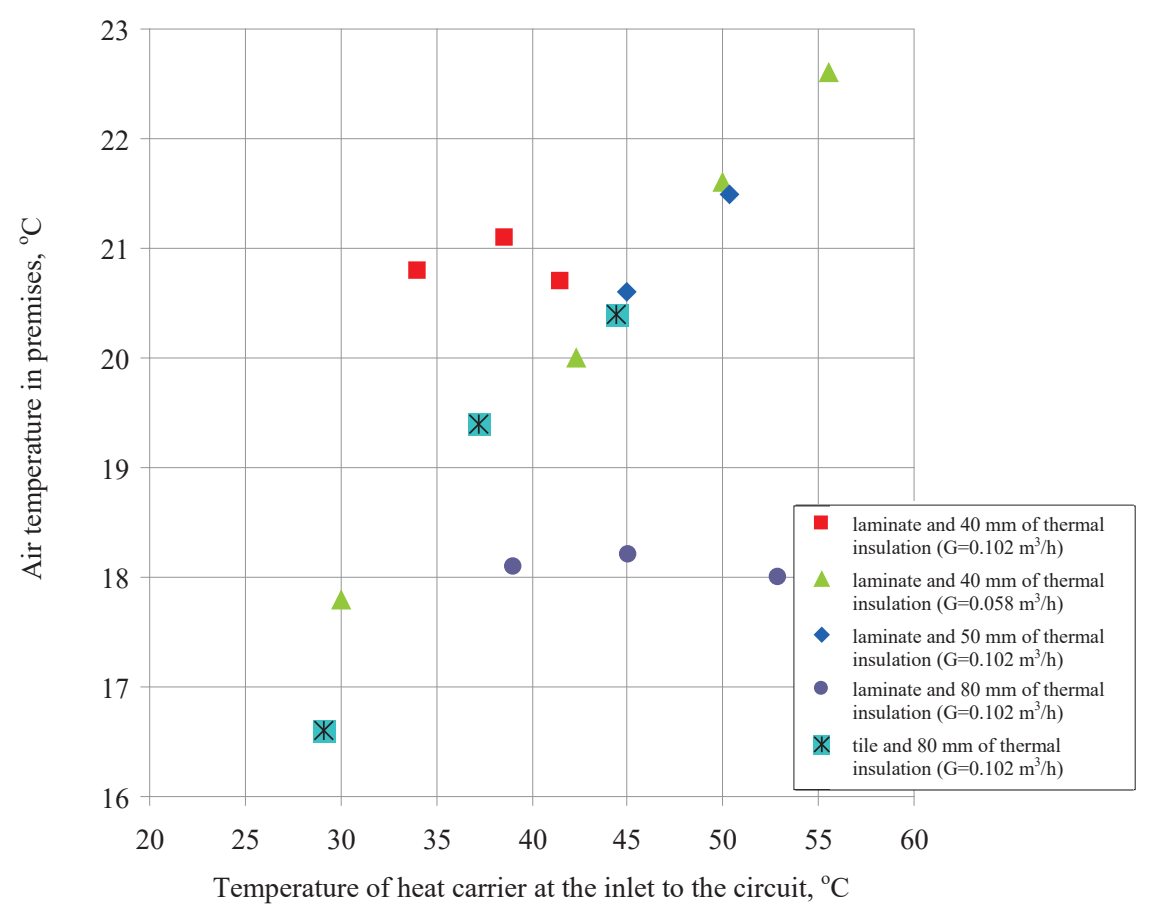

Fig. 5. Dependence of the heat carrier temperature at the inlet to the circuit of underfloor heating on the difference between average temperatures of heat carrier and air in the premises

That proves the thesis that the quantitative control over heat efficiency of low-temperature heating systems is not expedient. More effective in this case is the qualitative regulation of heat load with a change in the temperature of the heat carrier in the system. Increasing the thickness of thermal insulation by two times reduces, based on certain calculations, heat losses from the heat carrier in the circuit into space under the floor heating system by about $12 \%$. This, accordingly, leads to that a lower temperature of the finishing coating surface helps achieve compensation for the heat losses in the premises according to acting standards.

Fig. 4 demonstrates a substantial increase in the density of heat flow at the surface of ceramic tiles as a result of its lower thermal resistance and the denser (adhesive) contact with the aluminum heat distributor. Changing the values of flow rate of the heat carrier in the circuit insignificantly affects specific thermal flow from the surface of the laminate. Increasing the thickness of thermal insulation by $10 \mathrm{~mm}$ makes it possible to increase the density of heat flow at the surface of the floor by $5 \mathrm{~W} / \mathrm{m}^{2}$.

Fig. 5 shows that the air temperature in the premises rises higher in proportion to the growth in the temperature of heat carrier at the inlet. It should be noted that the average temperature of the outside air while conducting various experiments ranged, in each, respectively, from -7 to $3{ }^{\circ} \mathrm{C}$, which influenced heat losses in the premises. In most cases, almost all experimental variants of a heating system ensured the required thermal sanitary conditions.

\section{SWOT analysis of research results}

Strengths. Compared to analogues, a system of underfloor heating, assembled dry, has a number of advantages - low operation inertia, uniform distribution of the temperature field due to the application of an aluminum heat distributor, and ease of assembly.
Weaknesses. The weaknesses of a given system of underfloor heating include weak resistance to mechanical damage. Because this system lacks a monolithic concrete or cement pillow, a damage to the finishing coating may result in a very high probability of the depressurization of a heating circuit.

Opportunities. The experimental study that we conducted make it possible to further develop a mathematical model for the operation of an underfloor heating system, assembled dry. Employing the model would enable performing the optimization calculations to improve the design of a given heating device.

Threats. The application of the examined system of underfloor heating is associated with higher initial investments in comparison with similar heating devices. This relates to the use of aluminum in the structure of a heat distributor and a foam polystyrene plate with special slots.

\section{Conclusions}

1. We established in the course of our experimental studies the influence of thickness of a thermal insulating layer on the properties of heat transfer from the heat carrier to the air in the premises. A standard plate made of extruded foam polystyrene with a thickness of $40 \mathrm{~mm}$ is not capable to minimize heat losses into the floor under a floor heating system, assembled dry. This is explained by the design features of a given heating system - grooves under the circuit pipe decrease by almost twice the thermal insulating layer under it. Increasing the thickness of thermal insulation to $50 \mathrm{~mm}$ makes it possible to improve the operating efficiency of an underfloor heating system by $10 \%$ (density of the heat flow increases from 50 to $55 \mathrm{~W} / \mathrm{m}^{2}$ at a temperature of $20{ }^{\circ} \mathrm{C}$ in the premises). A further increase in the thickness of an insulating layer to $80 \mathrm{~mm}$ has not produced any significant effect. 
2. Considerable influence on the properties of heat transfer from the heat carrier to the air in the premises is exerted by a finishing coating. When using ceramic tiles and at the same consumption and temperature of the heat carrier at the inlet, the density of heat flow at the floor surface increased by $50 \%$ (from 57 to $86 \mathrm{~W} / \mathrm{m}^{2}$ at a temperature of $20{ }^{\circ} \mathrm{C}$ in the premises).

3 . The experimental research that we conducted allow us to argue about the system of underfloor heating, assembled dry, yielding a greater thermal maneuverability compared with a fill-in screed, as well as demonstrating a low heat-accumulating capacity. A small thermal-inertial component is achieved through the absence of a relatively thick layer of the monolithic concrete slab, inside which the heating system circuit is typically installed. The application of aluminum heat-distributing plates contributes to the levelling of a heat flow in the plane of the floor surface, which positively influences the heat distribution and reduces thermal stresses in the finishing coating. Executing the quantitative control over a thermal load of the system, owing to a change in the consumption of a heat carrier, turns out to be less effective than the qualitative regulation via changing its temperature.

\section{References}

1. Liu Y., Wang D., Liu J. Study on heat transfer process for inslab heating floor // Building and Environment. 2012. Vol. 54 P. 77-85. doi: http://doi.org/10.1016/j.buildenv.2012.02.007

2. Jin X., Zhang X., Luo Y. A calculation method for the floor surface temperature in radiant floor system // Energy and Buildings. 2010. Vol. 42. No. 10. P. 1753-1758. doi: http:// doi.org/10.1016/j.enbuild.2010.05.011

3. Simulation of the thermal state of the premises with the heating system «Heat-insulated floor» / Sotnik M. I. et al. // Eastern-European Journal of Enterprise Technologies. 2015. Vol. 6. No. 5 (78). P. $22-27$. doi: http://doi.org/10.15587/17294061.2015.56647

4. Romanchenko M., Slesarenko A., Kundenko M. Effect of thermal field distribution in the layered structure of a heating floor on the temperature of its surface // Eastern-European Journal of Enterprise Technologies. 2018. Vol. 1. No. 8 (91) P. 57-63. doi: http://doi.org/10.15587/1729-4061.2018.121827

5. Thermal performance of radiant heating floors in furnished enclosed spaces / Fontana L. et al. // Applied Thermal Engineering. 2011. Vol. 31. No. 10. P. 1547-1555. doi: http:// doi.org/10.1016/j.applthermaleng.2010.12.014
6. Zhang D., Cai N., Wang Z. Experimental and numerical analysis of lightweight radiant floor heating system // Energy and buildings. 2013. Vol. 61. P. 260-266. doi: http://doi.org/10.1016/ j.enbuild.2013.02.016

7. Modeling a radiant floor system with Phase Change Material (PCM) integrated into a building simulation tool: Analysis of a case study of a floor heating system coupled to a heat pump / Mazo J. et al. // Energy and Buildings. 2012. Vol. 47. P. 458-466. doi: http://doi.org/10.1016/j.enbuild.2011.12.022

8. Hasan A., Kurnitski J., Jokiranta K. A combined low temperature water heating system consisting of radiators and floor heating // Energy and Buildings. 2009. Vol. 41. No. 5. P. 470-479. doi: http:// doi.org/10.1016/j.enbuild.2008.11.016

9. Myhren J. A., Holmberg S. Flow patterns and thermal comfort in a room with panel, floor and wall heating // Energy and Buildings. 2008. Vol. 40. No. 4. P. 524-536. doi: http:// doi.org/10.1016/j.enbuild.2007.04.011

10. Study of the optimal control problem formulation for modulating air-to-water heat pumps connected to a residential floor heating system / Verhelst C. et al. // Energy and Buildings. 2012. Vol. 45. P. 43-53. doi: http://doi.org/10.1016/j.enbuild.2011.10.015

11. Isachenko V. P., Osipova V. A., Sukomel A. C. Teploperedacha. Moscow, 1981. 416 p.

12. Nizovtsev M. I., Sakharov I. A. Opredelenie teplovykh i konstruktivnykh parametrov vodyanogo teplogo pola: proceedings // Energo- i resursoeffektivnost' maloetazhnykh zhilykh zdaniy. Institut teplofiziki im. S.S. Kutateladze SO RAN. 2013. P. 39-43.

Basok Boris, Doctor of Technical Sciences, Professor, Head of the Department of Thermophysical Basics of Energy-Saving Technologies, Institute of Engineering Thermophysics of the National Academy of Sciences of Ukraine, Kyiv, Ukraine, e-mail: basok@ittf.kiev.ua, ORCID: http://orcid.org/0000-0002-8935-4248

Tkachenko Myroslav, PhD, Senior Researcher, Department of Thermophysical Basics of Energy-Saving Technologies, Institute of Engineering Thermophysics of the National Academy of Sciences of Ukraine, Kyiv, Ukraine, e-mail: tkamyr@gmail.com, ORCID: http:// orcid.org/0000-0001-8345-1613

Nedbailo Aleksandr, PhD, Senior Researcher, Department of Thermophysical Basics of Energy-Saving Technologies, Institute of Engineering Thermophysics of the National Academy of Sciences of Ukraine, Kyiv, Ukraine, e-mail: nan_sashulya@ukr.net, ORCID: http://orcid.org/0000-0003-1416-9651

Bozhko Igor, PhD, Researcher, Department of Thermophysical Basics of Energy-Saving Technologies, Institute of Engineering Thermophysics of the National Academy of Sciences of Ukraine, Kyiv, Ukraine, e-mail: bozhkoik@gmail.com, ORCID: https://orcid.org/ 0000-0001-7458-0835 